\title{
Sebaran Disparitas Antar Daerah di Kabupaten Banyumas
}

\author{
Dede Prabowo Wiguna \\ Alumni FMIPA Universitas Indonesia \\ Dosen Tetap di Sekolah Tinggi Ilmu Komputer (STIKOM) \\ Anggota IPLBI (Ikatan Peneliti Lingkungan Binaan Indonesia) \\ Email: dede.prabowo@alumni.ui.ac.id
}

Diterima: 12 April 2016; Disetujui: 27 Agustus 2016; Dipublikasikan: 4 November 2016

Permalink/DOI: http://dx.doi.org/10.17977/um002v8i22016p141

\begin{abstract}
This study aims to examine regional disparities in Banyumas. Feature disparities such as slums and congestion being targeted research. In addition, connectivity become an integral part of this research by looking at the disparity of road infrastructure network. The results of this study indicate that by Williamson Index disparities between regions is small. However, if comparing with the dynamic economic approach of the GDP - capita looks different and Banyumas looked disparity, which is based on data obtained that the highest achievements is owned by a large part in Purwokerto area. From geography to numbers cynclomatic approach looks balanced regional development in the area of Purwokerto. The density of this area is also very high which when done observation, local slums and congestion are only found in the Purwokerto area and not in other areas within the administrative area of Banyumas. This arises from the polarization of development in the eastern part of Banyumas.
\end{abstract}

Keywords: Disparity, Economic Approach, Geography Approach

JEL Classification: F63, R11

\section{PENDAHULUAN}

Masalah disparitas pembangunan adalah masalah yang cukup besar dan kompleks. Hal ini menjadi sorotan yang begitu tajam, sebab lahirnya UU Republik Indonesia Nomor 32 Tahun 2004 tentang Pemerintahan Daerah dan UU Republik Indonesia Nomor 33 Tahun 2004 tentang Perimbangan Keuangan antara Pemerintahan Pusat dan Pemerintahan Daerah pada dasarnya dalam kerangka untuk otonomi dan pemerataan pendapatan daerah. Namun, faktanya masih terdapat kesenjangan dan disparitas di daerah-daerah.

Berdasarkan studi pendahuluan yang telah dilakukan dapat dideskripsikan daerah Kabupaten Banyumas secara umum terbagi pada tiga karakteristik daerah. Pertama, Kepadatan Penduduk Tinggi - Sangat Tinggi banyak mengelompok di daerah bagian timur dan tengah. Dimana pada daerah ini memiliki topografi (kelerengan) yang relatif datar. Kedua, Kepadatan Penduduk Sedang banyak terdapat di daerah tengah dan selatan. Daerah ini topografinya sebagian relatif landai. Ketiga, Kepadatan Penduduk Rendah terdapat di daerah utara dan barat. Dimana topografi daerah ini relatif agak curam - sangat curam. Dengan variasi kepadatan dan topografi yang beragam berdampak pada pembangunan sehingga dapat menimbulkan disparitas antar daerah dan pembangunan yang tidak merata. 
Dimana hal ini terdeskripsikan dari struktur PDRB per kapita Kabupaten Banyumas atas dasar harga konstan tahun 2008 diketahui bahwa kecamatan yang memiliki nilai PDRB per kapita dibawah PDRB per kapita kabupaten adalah Kecamatan Lumbir, Jatilawang, Rawalo, Kebasen, Kemranjen, Sumpiuh, Tambak, Somagede, Kalibagor, Patikraja, Gumelar, Pekuncen, Cilongok, Karanglewas, Kedung-banteng, Baturaden, Sumbang, dan Kembaran. Sedangkan kecamatan yang memiliki nilai PDRB Per Kapita diatas PDRB Per Kapita Kabupaten adalah Kecamatan Wangon, Banyumas, Purwojati, Ajibarang, Sokaraja, Purwokerto Selatan, Purwokerto Barat, Purwokerto Timur, dan Purwokerto Utara

Disparitas antar daerah sebagaimana menurut Rustiadi dkk. (2011) mengatakan bahwa ketidakseimbangan pembangunan antar-daerah menimbulkan penyakit "urbanisasi" yang dicirikan dengan bentuk ketidakefisienan dan permasalahan seperti munculnya kawasan kumuh, tingginya polusi, tingginya kemacetan, kriminalitas pada perkotaan. Atas dasar teori Rustiadi dkk. (2011) tersebut maka menarik untuk ditelaah lebih lanjut mengenai disparitas antar daerah khususnya pada tingkat kecamatan di Kabupaten Banyumas. Ciri dari disparitas seperti Kawasan Kumuh dan Kemacetan menjadi sasaran yang dapat dijadikan studi dispartias antar daerah di Kabupaten Banyumas. Untuk menelaah lebih jauh terkait masalah disparitas, dipertegas juga dalam dokumen MP3EI 2011-2025 dimana penguatan konektifitas menjadi salah satu dari pilar utama. Hal ini tidak lain adalah untuk memperbaiki ketimpangan spasial. Kemudian, dalam kegiatan mengukur secara ekonomi dan geografi diperlukan pendekatan yang sesuai sehingga akan didapatkan deskripsi indeks ketimpangan antar daerah. Berdasarkan latar belakang ini maka kajian disparitas antar daerah di Kabupaten Banyumas menarik untuk dikaji lebih lanjut.

\section{KAJIAN PUSTAKA \\ Teori Disparitas Antar Daerah}

Disparitas regional merupakan fenomena universal (Krimi dkk, 2010; Mohiuddin \& Hashia, 2012). Di semua negara tanpa memandang ukuran dan tingkat pembangunan, disparitas pembangunan merupakan masalah pembangunan antar daerah yang tidak merata. Pada banyak Negara, pembagian ekonomi tidak merata telah melahirkan masalah-masalah sosial politik. Hampir disemua negara baik pada sistem perekonomian pasar maupun ekonomi terencana secara terpusat, kebijakan-kebijakan pembangunan diarahkan untuk mengurangi disparitas antar daerah (Rustiadi dkk, 2011; Ascani dkk, 2012).

Faktor-faktor yang menyebabkan terjadinya disparitas antar-daerah menurut Rustiadi dkk (2011) terkait dengan variabel-variabel fisik dan sosial ekonomi daerah. Faktor utama ini antara lain adalah: (1) geografi); (2) sejarah; (3) politik; (4) kebijakan pemerintah; (5) administrasi; (6) sosial budaya; dan (7) ekonomi. Pada suatu daerah yang cukup luas akan terjadi variasi spasial kuantitas dan kualitas sumberdaya mineral, sumberdaya pertanian, topografi, iklim, curah hujan, dan sebagainya. Apabila faktor-faktor lain sama, maka kondisi geografi yang lebih baik akan berkembang lebih baik. 


\section{Mengukur Disparitas Antar Daerah Pendekatan Ekonomi}

Rustiadi dkk (2011) menjelaskan secara khusus untuk melihat disparitas dilakukan dengan pengukuran secara ekonomi dengan dua cara, yaitu pendekatan statis dan dinamis. Pendekatan statis dapat dilakukan dengan mengukur secara deskriptif dengan membandingkan PDRB, pertumbuhan PDRB, atau PDRB perkapita antar daerah. Kesenjangan statis antar daerah secara lebih terukur dapat dilakukan dengan menggunakan indeks kesenjangan spasial seperti Williamson Index.

\section{Deskripsi Penduduk dan PDRB}

Secara deskriptif kesenjangan pembangunan antar daerah dapat dilakukan dengan perbandingan secara langsung antara proporsi penduduk, luas daerah dengan proporsi kontribusi daerah terhadap PDRB secara keseluruhan (PDRB Nasional).

\section{Indeks Williamson}

Indeks Williamson merupakan salah satu indeks yang paling sering digunakan untuk melihat disparitas antardaerah. Pengukuran didasarkan pada variasi hasil-hasil pembangunan ekonomi antar daerah yang berupa besaran PDRB. Kriteria pengukuran adalah semakin besar nilai indeks yang menunjukkan variasi produksi ekonomi antar daerah semakin besar pula tingkat perbedaan ekonomi dari masing-masing daerah dengan rata-ratanya, sebaliknya semakin kecil nilai menunjukkan kemerataan antar daerah yang baik.

\section{Pendekatan Geografi}

Pendekatan geografi untuk menjelaskan ketimpangan antar daerah dapat diukur dengan angka sinklomatik. Bintarto \& Hadisumarno (1991) menjelaskan bahwa jaringan dan perjalanan (journey) sangat erat hubungannya sehingga sukar untuk dipisahkan satu sama lain. Secara umum dapat dijelaskan bahwa transportasi dan komunikasi antar tempat dapat dicapai melalui salah satu ruang seperti: a. melalui mata rantai yang jelas batasnya seperti jelan kendaraan bermotor, jalur pipa, jalan kereta api dan lain sebagainya, b. mata rantai yang tidak jelas batasnya seperti jalur pesawat terbang dan jalur kapal laut, dan c. mata rantai yang batasnya kabur sekali seperti radio.

Lebih lanjut Bintarto \& Hadisumarno (1991) menjelaskan bahwa beberapa indeks digunakan untuk menunjukkan konektifitas sesuatu graf. Salah satu indeks tersebut adalah angka sinklomatik (cyclomatic number). Angka sinklomatik dapat digunakan untuk membandingkan jaringan jalan dari dua daerah. Daerah dengan angka sinklomatik yang tinggi menunjukkan bahwa jaringan jalannya lebih rapat. Hal ini ada hubungannya dengan tingkat perkembangan ekonomi daerah tersebut.

\section{Pendekatan Permukiman Kumuh}

Pengertian permukiman kumuh dapat dijabarkan menurut perspektif ahli dan pemerintah. Seperti yang dikemukakan ahli, Khomarudin (1997) lingkungan permukiman kumuh dapat didefinisikan sebagai berikut:

1. Lingkungan yg berpenghuni padat (melebihi 500 org per $\mathrm{Ha}$ )

2. Kondisi sosial ekonomi masyarakat rendah 
3. Jumlah rumahnya sangat padat dan ukurannya dibawah standar

4. Sarana prasarana tidak ada atau tidak memenuhi syarat teknis dan kesehatan

5. Hunian dibangun diatas tanah milik negara atau orang lain dan diluar perundang-undangan yang berlaku.

Selain itu, lingkungan kumuh dapat dideskripsikan sebagai berikut: a. Lingkungan permukiman yang kondisi tempat tinggal atau tempat huniannya berdesakkan, b. Luas rumah tidak sebanding dengan jumlah penghuni, c. Rumah hanya sekedar tempat untuk berlindung dari panas dan hujan, d. Hunian bersifat sementara dan dibangun di atas tanah bukan milik penghuni, e. Lingkungan dan tata permukimannya tidak teratur tanpa perencanaan, f. Prasarana kurang (mck, air bersih, saluran buangan, listrik, jalan lingkungan), g. Fasilitas sosial kurang (sekolah, rumah ibadah, balai pengobatan, h. Mata pencaharian yang tidak tetap dan usaha non formal, i. Pendidikan masyarakat rendah.

Khomarudin (1997) juga menjelaskan penyebab utama tumbuhnya lingkungan kumuh antara lain:

1. Urbanisasi dan migrasi yang tinggi terutama bagi kelompok masyarakat berpenghasilan rendah,

2. Sulit mencari pekerjaan,

3. Sulitnya mencicil atau menyewa rumah,

4. Kurang tegasnya pelaksanaan perundang-undangan,

5. Perbaikan lingkungan yang hanya dinikmati oleh para pemilik rumah serta

6. Disiplin warga yang rendah,

7. Kota sebagai pusat perdagangan yang menarik bagi para pengusaha,

8. Semakin sempitnya lahan permukiman dan tingginya harga tanah

Dalam perspektif pemerintah yakni menurut Direktorat Jenderal Perumahan dan Permukiman (2011), Tingkatan Kekumuhan Lingkungan Permukiman, dijelaskan sebagai berikut antara lain:

1. Kawasan Kumuh Diatas Tanah Legal, yang dimaksud dengan kawasan kumuh legal adalah permukiman kumuh (dengan segala ciri sebagaimana disampaikan dalam kriteria) yang berlokasi diatas lahan yang dalam RUTR memang diperuntukkan sebagai zona perumahan.

2. Kawasan Kumuh Diatas Tanah Tidak Legal, yang dimaksudkan dengan tanah tidak legal ini adalah kawasan permukiman kumuh yang dalam RUTR berada pada peruntukan yang bukan perumahan. Disamping itu penghuniannya dilakukan secara tidak sah pada bidang tanah; baik milik negara, milik perorangan atau Badan Hukum. Contoh nyata dari kondisi ini antara lain; permukiman yang tumbuh disekitar TPA (tempat pembuangan akhir persampahan), kantung-kantung kumuh sepanjang bantaran banjir, kantung kumuh yang berasa dibelakang bangunan umum dalam suatu kawasan fungsional, dll.

\section{METODE}

Penelitian ini menggunakan teknik analisis campuran yaitu dengan analisis ekonomi (pendekatan Indeks Williamson dan PDRB) serta menggunakan analisis geografi (pendekatan angka sinklomatik). Secara garis besar, bahan yang digunakan pada penelitian ini yaitu data primer (observasi serta dokumentasi kemacetan lalu lintas dan lokasi permukiman kumuh) dan data sekunder terbaru 
2012-2014 (Citra SRTM, Kepadatan Penduduk, PDRB Perkapita Kabupaten dan PDRB Perkapita Kecamatan, Peta Infrastruktur Jaringan Jalan, Peta Kelerengan Lahan, Perumahan dan Permukiman Kumuh). Alat yang digunakan untuk pemetaan adalah ArcGIS 10.1

\section{HASIL DAN PEMBAHASAN}

Berdasarkan Tabel 1. bahwa hasil perhitungan dari Pemerintah Banyumas Indeks Williamson Kabupaten Banyumas Tahun 2014 adalah sebesar 0,0114. Sedangkan berdasarkan Tabel 2. yaitu Indeks Williamson berdasarkan perhitungan Penulis. didasarkan dengan data PDRB Perkapita Atas Harga Konstan, yang menunjukkan dan memberikan gambaran disparitas yang hampir sama. Dimana Indeks Williamson dapat diketahui secara keseluruhan yaitu sebesar 0,0002. Keterangan; $\mathrm{Vw}=$ Indeks kesenjangan, $\mathrm{Yi}=\mathrm{PDRB}$ per kapita kecamatan ke-i, Y = Rata-rata PDRB perkapita Kab. Banyumas, Pi = fi/n, dimana fi jumlah penduduk kecamatan ke-I dan n adalah total penduduk Kab. Banyumas. Penulis tidak mengetahui secara pasti mengapa ada perbedaan perhitungan nilai indeks ketimpangan tersebut. Namun, kedua nilai indeks tersebut dapat ditarik kesimpulan kedua menunjukkan ketimpangan antar daerah yang relative kecil.

Tabel 1. Indeks Williamson Hasil Perhitungan Pemerintah Kabupaten Banyumas (Pendekatan Ekonomi Statis)

\begin{tabular}{clccccc}
\hline No & Kecamatan & PDRB/Kapita & Penduduk & $(\mathbf{Y}-\mathbf{Y b a r})^{\wedge} \mathbf{2}$ & (fi/n) & IW \\
\hline 1 & Lumbir & $2,309,896$ & 43,986 & 712542,08 & 0,03 & 19861,03 \\
\hline 2 & Wangon & $3,474,481$ & 74,157 & 102696,49 & 0,05 & 4825,97 \\
\hline 3 & Jatilawang & $2,846,703$ & 57,916 & 94442,55 & 0,04 & 3466,12 \\
\hline 4 & Rawalo & $2,555,815$ & 45,956 & 357846,92 & 0,03 & 10421,16 \\
\hline 5 & Kabasen & $1,855,306$ & 56,594 & 1686653,05 & 0,04 & 60488,51 \\
\hline 6 & Kamranjen & $1,905,327$ & 63,333 & 1559229,40 & 0,04 & 62577,30 \\
\hline 7 & Sumpiuh & $2,582,467$ & 50,547 & 326670,63 & 0,03 & 10463,63 \\
\hline 8 & Tambak & 2309882 & 42,55 & 712565,71 & 0,03 & 19213,27 \\
\hline 9 & Somagede & $3,283,774$ & 32,309 & 16836,60 & 0,02 & 344,71 \\
\hline 10 & Kalibagor & $3,054,068$ & 46,655 & 9990,02 & 0,03 & 295,35 \\
\hline 11 & Banyumas & $3,704,339$ & 46,309 & 302853,12 & 0,03 & 8887,39 \\
\hline 12 & Patikraja & $2,253,368$ & 51,112 & 811170,56 & 0,03 & 26273,13 \\
\hline 13 & Purwojati & $3,392,279$ & 31,271 & 56768,17 & 0,02 & 1124,93 \\
\hline 14 & Ajibarang & $3,124,925$ & 91,266 & 846,41 & 0,06 & 48,95 \\
\hline 15 & Gumelar & $1,728,691$ & 45,842 & 203157,27 & 0,03 & 59015,95 \\
\hline 16 & Pekuncen & $1,875,304$ & 65,399 & 1635109,68 & 0,04 & 67763,33 \\
\hline 17 & Cilongok & $2,742,354$ & 110,509 & 169467,31 & 0,07 & 11867,53 \\
\hline 18 & Karang & 2227,96 & 58,006 & 857583,56 & 0,04 & 31522,90 \\
& Lewas & & & & & \\
\hline 19 & Kedung & 2243,23 & 51,898 & 829534,92 & 0,03 & 27281,11 \\
& Banteng & & & & & \\
\hline 20 & Baturaden & $2,801,286$ & 47,867 & 124419,92 & 0,03 & 3774,01 \\
\hline 21 & Sumbang & 1876,68 & 75,772 & 1631592,56 & 0,05 & 78342,46 \\
\hline 22 & Kembaran & $2,361,754$ & 73,244 & 627682,36 & 0,05 & 29133,24 \\
\hline 23 & Sokaraja & 3186424 & 78,071 & 1050,14 & 0,05 & 51,95 \\
\hline 24 & Purwokerto & $3,998,921$ & 71,588 & 713860,95 & 0,05 & 32384,01 \\
& Selatan & & & & & \\
\hline 25 & Purwokerto & $6,298,739$ & 49,825 & 9889269,70 & 0,03 & 312239,82 \\
& Barat & & & & & \\
\hline 26 & Purwokerto & $12,428,399$ & 57,975 & 86014141,56 & 0,04 & 3160002,17 \\
\hline & & & & & & \\
\hline 1 & & & & & \\
\hline
\end{tabular}




\begin{tabular}{ccccccc}
\hline No & Kecamatan & PDRB/Kapita & Penduduk & (Y-Ybar) $^{\wedge} \mathbf{2}$ & (fi/n) & IW \\
\hline & Timur & & & & & \\
\hline 27 & $\begin{array}{l}\text { Purwokerto } \\
\text { Utara }\end{array}$ & $2,736,116$ & 58,102 & 174642,14 & 0,04 & 6430,09 \\
\hline & & $\mathbf{2 8 9 8 , 6}$ & $\mathbf{1 5 5 4 , 5}$ & & Jumlah & $\mathbf{4 0 4 8 1 0 0 , 0 2}$ \\
\hline & & & & Akar & 35,83 \\
\hline & & & & Wiliamson & $\mathbf{0 , 0 1 1 4}$ \\
\hline
\end{tabular}

Sumber: Bappeda Kab. Banyumas Tahun 2014

Indeks Williamson ditunjukkan oleh angka 0 sampai angka 1 atau $0<\mathrm{VW}$ $<$ 1. Jika Indeks Williamson semakin mendekati angka 0 maka semakin kecil ketimpangan pembangunan ekonomi dan jika Indeks Wlliamson semakin mendekati angka 1 maka semakin besar ketimpangannya. Dengan demikian, maka ketimpangan ekonomi secara keseluruhan di Kabupaten Banyumas tergolong kecil. Namun, jika menganalisis dari PDRB Perkapita setiap kecamatan melalui pendekatan dinamis akan tampak perbedaan pendapatan yang memberikan informasi disparitas antar daerah.

Tabel 2. Index Williamson Hasil Penghitungan Penulis (Pendekatan Ekonomi Statis)

\begin{tabular}{|c|c|c|c|c|}
\hline No & Kecamatan & $\begin{array}{c}\text { PDRB Perkapita } \\
\text { Harga Konstan (Rp) }\end{array}$ & $\mathrm{Yi}-\mathrm{Y}^{2} . \mathrm{Pi}$ & $\begin{array}{c}\mathrm{Vw}= \\
\sqrt{\Sigma(Y i-Y)^{2} \mathrm{Pi}}\end{array}$ \\
\hline & & 2421651 & 20353304325 & $\mathrm{Y}$ \\
\hline 1 & Lumbir & 2.421 .651 & 20353304325 & \\
\hline 2 & Wangon & 3.646 .299 & 6195850906 & \\
\hline 3 & Jatilawang & 2.982 .303 & 3258457350 & \\
\hline 4 & Rawalo & 2.664 .942 & 11006134762 & \\
\hline 5 & Kebasen & 1.936 .324 & 64411706593 & \\
\hline 6 & Kemranjen & 1.980 .165 & 67803301933 & \\
\hline 7 & Sumpiuh & 2.706 .670 & 10487524059 & \\
\hline 8 & Tambak & 2.424 .283 & 19566767591 & \\
\hline 9 & Somagede & 3.423 .216 & 407944081.2 & \\
\hline 10 & Kalibagor & 3.177 .554 & 319384721.2 & \\
\hline 11 & Banyumas & 3.900 .506 & 11095623859 & \\
\hline 12 & Patikraja & 2.328 .248 & 29545043280 & \\
\hline 13 & Purwojati & 3.543 .600 & 1348177360 & \\
\hline 14 & Ajibarang & 3.255 .499 & 39469735.87 & \\
\hline 15 & Gumelar & 1.812 .907 & 61860148889 & \\
\hline 16 & Pekuncen & 1.963 .921 & 71171261521 & \\
\hline 17 & Cilongok & 2.839 .578 & 13746321013 & \\
\hline 18 & Karanglewas & 2.280 .244 & 37414521265 & \\
\hline 19 & Kedungbanteng & 2.315 .169 & 30780174940 & \\
\hline 20 & Baturraden & 2.880 .037 & 4941016396 & \\
\hline 21 & Sumbang & 1.923 .310 & 89557285669 & \\
\hline 22 & Kembaran & 2.408 .850 & 35968372305 & \\
\hline 23 & Sokaraja & 3.279 .040 & 339861.1861 & \\
\hline 24 & Purwokerto Selatan & 4.129 .395 & 32846807547 & \\
\hline 25 & Purwokerto Barat & 6.537 .187 & 335311 & \\
\hline 26 & Purwokerto Timur & 13.066 .709 & 347311 & \\
\hline \multirow[t]{2}{*}{27} & Purwokerto Utara & 2.776 .844 & 9590306478 & \\
\hline & & $Y=3.281 .646,333$ & $\sum=444214$ & 0.0002 \\
\hline
\end{tabular}


Berdasarkan Tabel 3. bahwa daerah yang memiliki PDRB Perkapita tertinggi ada di daerah bagian timur Kab. Banyumas seperti Purwokerto Timur (Rp. 13.066.709), Purwokerto Barat (Rp. 6.537.187), Purwokerto Selatan (Rp. 4.129.395) yang seperti terlihat pada diagram alir penelitian daerah bagian timur ini merupakan daerah yang tergolong kepadatan penduduknya sangat tinggi. Dari nilai PDRB Perkapita ini dapat diartikan bahwa lokasi ataupun daerah yang menjadi pusat aktivitas ekonomi terjadi di daerah timur sehingga pembangunan tampak tidak merata di daerah lainnya. Misalnya daerah tengah, utara, barat dan selatan Kabupaten Banyumas sehingga dapat tergambar terjadi disparitas antar daerah.

Tabel 3. PDRB Harga Konstan/Per Kecamatan (Pendekatan Ekonomi Statis)

\begin{tabular}{cccc}
\hline Nama Kecamatan & $\begin{array}{c}\text { PDRB Harga } \\
\text { Konstan }\end{array}$ & Nama Kecamatan & PDRB Harga Konstan \\
\hline Lumbir & 2.421 .651 & Ajibarang & 3.255 .499 \\
\hline Wangon & 3.646 .299 & Gumelar & 1.812 .907 \\
\hline Jatilawang & 2.982 .303 & Pekuncen & 1.963 .921 \\
\hline Rawalo & 2.664 .942 & Cilongok & 2.839 .578 \\
\hline Kebasen & 1.936 .324 & Karanglewas & 2.280 .244 \\
\hline Kemranjen & 1.980 .165 & Kedungbanteng & 2.315 .169 \\
\hline Sumpiuh & 2.706 .670 & Baturraden & 2.880 .037 \\
\hline Tambak & 2.424 .283 & Sumbang & 1.923 .310 \\
\hline Somagede & 3.423 .216 & Kembaran & 2.408 .850 \\
\hline Kalibagor & 3.177 .554 & Sokaraja & 3.279 .040 \\
\hline Banyumas & 3.900 .506 & Purwokerto Selatan & 4.129 .395 \\
\hline Patikraja & 2.328 .248 & Purwokerto Barat & 6.537 .187 \\
\hline Purwojati & 3.543 .600 & Purwokerto Timur & 13.066 .709 \\
\hline & & Purwokerto Utara & 2.776 .844 \\
\hline
\end{tabular}

Sumber: RPJMD Kab. Banyumas $2013-2018$

Lebih lanjut, dengan Pendekatan Geografi menggunakan Cynclomatic Number (Angka Sinklomatik) yang sudah dilakukan perhitungan Penulis mendapatkan hasil bahwa daerah atau kecamatan yang dikategorikan paling lambat perkembangan ekonominya terletak di Kecamatan Gumelar dan Kedungbanteng dengan Angka Sinklomatik sebesar - 1. Untuk daerah / kecamatan dengan kategori paling cepat berkembang adalah daerah atau Kecamatan Sokaraja dan Kecamatan Patikraja dimana masing-masing dengan Angka Sinklomatik $(\mu)$ sebesar 5. Untuk daerah Purwokerto (Barat, Timur, Selatan) perkembangan ekonominya relatif sedang dan agak berbeda terjadi perkembangan ekonomi yang lambat terjadi pada Kecamatan Purwokerto Utara dimana Angka Sinklomatik $(\mu)$ sebesar 1.

Tabel 4. Hasil Perhitungan Angka Sinklomatik ( $\mu$ ) (Pendekatan Geografi)

\begin{tabular}{cccccc}
\hline $\begin{array}{c}\text { Nama } \\
\text { Kecamatan }\end{array}$ & $\begin{array}{c}\text { Hasil } \\
\text { Perhitungan }\end{array}$ & $\begin{array}{c}\text { Angka } \\
\text { Sinklomatik } \\
(\boldsymbol{\mu})\end{array}$ & $\begin{array}{c}\text { Nama } \\
\text { Kecamatan }\end{array}$ & $\begin{array}{c}\text { Hasil } \\
\text { Perhitungan }\end{array}$ & $\begin{array}{c}\text { Angka } \\
\text { Sinklomatik } \\
(\boldsymbol{\mu})\end{array}$ \\
\hline Lumbir & $2-1+1=2$ & 2 & Ajibarang & $4-1+1=4$ & 4 \\
\hline Wangon & $4-1+1=4$ & 4 & Gumelar & $0-1+0=-1$ & -1 \\
\hline Jatilawang & $3-1+1=3$ & 3 & Pekuncen & $3-1+2=4$ & 4 \\
\hline Rawalo & $4-1+1=4$ & 4 & Cilongok & $3-1+2=4$ & 4 \\
\hline Kebasen & $3-1+1=3$ & 3 & Karanglewas & $2-1+2=3$ & 3 \\
\hline
\end{tabular}




\begin{tabular}{cccccc}
\hline Kemranjen & $3-1+2=4$ & 4 & $\begin{array}{c}\text { Kedung } \\
\text { banteng }\end{array}$ & $0-1+0=-1$ & -1 \\
\hline Sumpiuh & $3-1+1=3$ & 3 & Baturaden & $1-1+1=1$ & 1 \\
\hline Tambak & $4-1+1=4$ & 4 & Sumbang & $1-1+1=1$ & 1 \\
\hline Somagede & $2-1+1=2$ & 2 & Kembaran & $2-1+1=2$ & 2 \\
\hline Kalibagor & $3-1+2=4$ & 4 & Sokaraja & $5-1+1=5$ & 5 \\
\hline Banyumas & $3-1+1=3$ & 3 & $\begin{array}{c}\text { Purwokerto } \\
\text { Selatan }\end{array}$ & $2-1+2=3$ & 3 \\
\hline Patikraja & $4-1+2=5$ & 5 & $\begin{array}{c}\text { Purwokerto } \\
\text { Barat }\end{array}$ \\
\hline Purwojati & $1-1+1=1$ & 1 & $\begin{array}{c}\text { Purwokerto } \\
\text { Timur }\end{array}$ \\
\hline \multicolumn{5}{c}{$\begin{array}{c}\text { Purwokerto } \\
\text { Utara }\end{array}$} \\
\hline \multicolumn{5}{c}{$1-1+1+1=3$} \\
\hline
\end{tabular}

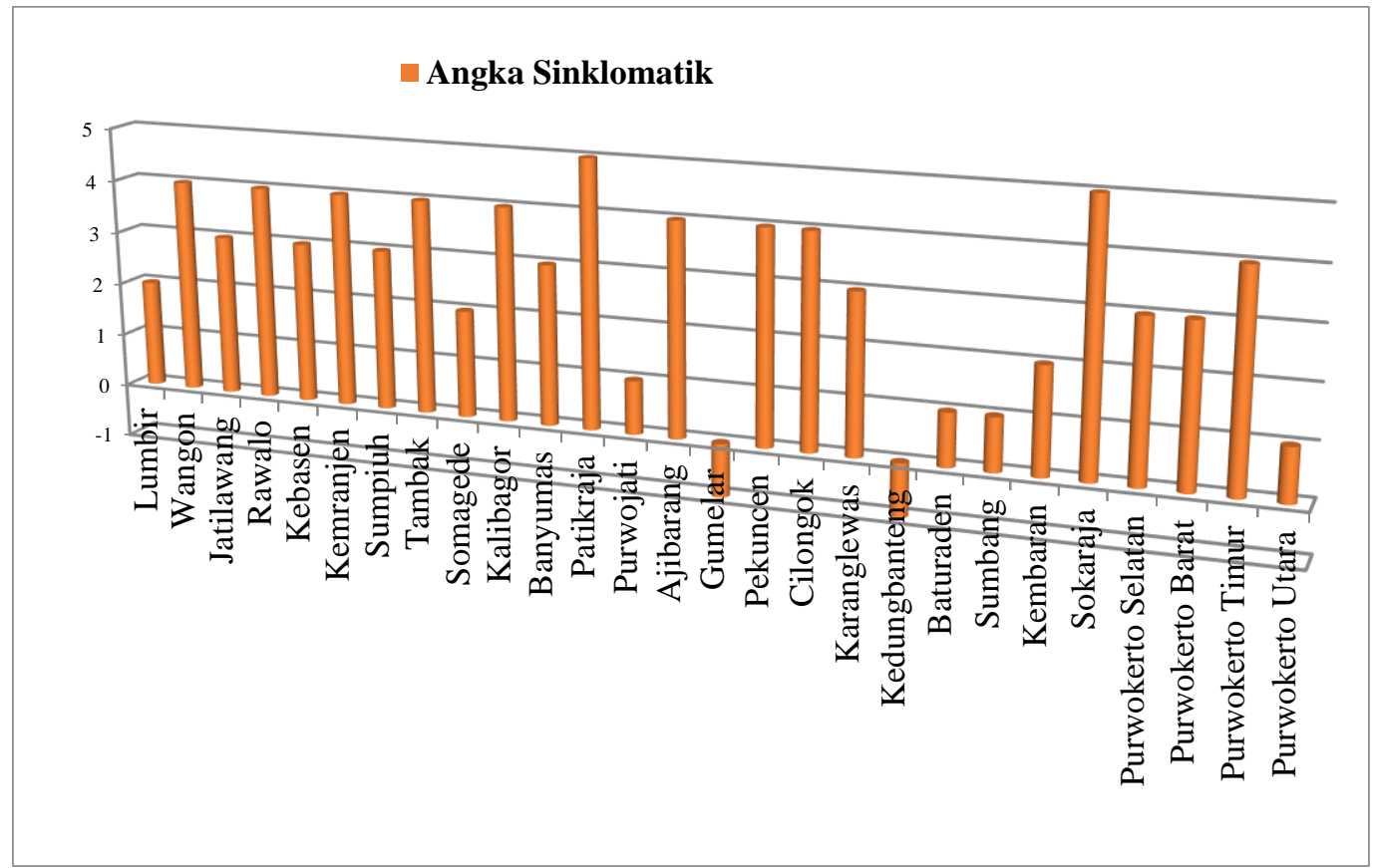

Gambar 1. Peta Infrastuktur Kab. Banyumas

Sumber: Peta Infrastruktur Kab. Banyumas Kementerian PU Tahun 2012 (data diolah) Variabel: Jaringan Jalan Nasional, Jalan Provinsi, Jalan Kabupaten, Rel Kereta Api

Dengan meng-cluster data Kepadatan Penduduk dan data Kelerengan Lahan tampak bahwa sebaran disparitas antar daerah. Pertama, berdasarkan Peta Sebaran Disparitas pada bagian timur Kab. Banyumas terjadi dominasi Kepadatan Penduduk Sangat Tinggi dan memiliki tingkat perkembangan ekonomi rata-rata cepat. Pada daerah dengan Kepadatan Penduduk Rendah - Sedang terjadi rata-rata perkembangan relatif lambat. Pada daerah ini terletak Kecamatan dengan disparitas yang cukup tinggi (Angka Sinklomatik -1) tepatnya di Kecamatan Kedungbanteng. Dibagian tengah Kabupaten Banyumas tampak lebih sedikit merata perkembangan-nya dan cukup baik, dengan Kepadatan Penduduk Rendah - Tinggi angka sinklomatiknya rata-rata banyak 3-4 (sedang) bahkan ada yang angka sinklomatik 5 (cepat) yaitu di Kecamatan Patikraja.

Namun, berdasarkan data-data yang didapatkan tersebut, yang sedikit ada disparitas terletak di Kecamatan Purwojati. Kecamatan ini kepadatan penduduknya rendah dengan tingkat perkembangan ekonominya juga lambat 
(angka sinklomatik 1). Pada bagian selatan perkembangannya terlihat lebih baik dan lebih merata. Kepadatan Penduduk Rendah - Sedang dengan tingkat perkembangan sedang (Angka Sinklomatik 3-4), hal ini menunjukkan bahwa disparitasnya kecil. Dengan demikian, dapat ditarik kesimpulan bahwa perkembangan ekonomi pada daerah ini relatif merata (Lessmann, 2011).

Berbeda dengan bagian barat, daerah ini terjadi disparitas cukup besar dimana perkembangan cepat (angka sinklomatik 4) pada Kecamatan Pekuncen dengan Kepadatan Penduduk Rendah. Sedangkan pada kecamatan lain, misalnya di Kecamatan Gumelar dan Lumbir dengan Kepadatan Penduduk Rendah perkembangan ekonominya lambat (Angka Sinklomatik secara berurutan -1 dan 1). Dari analisis Peta Sebaran Disparitas Antar Daerah, maka secara keseluruhan tingkat perkembangan ekonomi yang lebih merata terletak di Bagian Tengah dan Selatan Kabupaten Banyumas dengan rata-rata Kepadatan Sedang serta perkembangan ekonomi dikategorikan Sedang (Angka Sinklomatik 3-4).

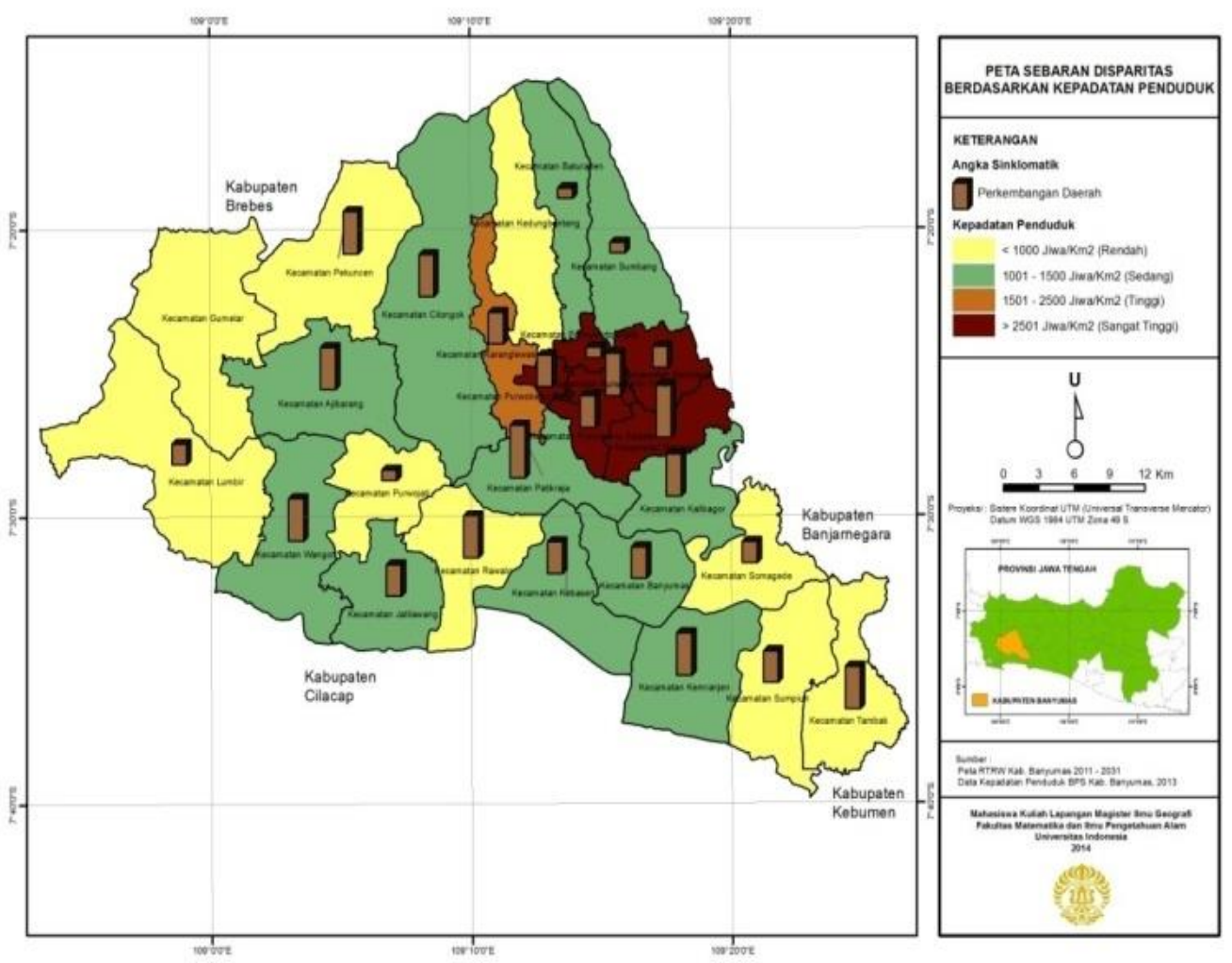

Gambar 2. Sebaran Disparitas Berdasarkan Kepadatan Penduduk

Kedua, tampak secara umum dari Peta Sebaran Disparitas Berdasarkan Kelerengan Lahan menunjukkan keselarasan dengan perkembangan penduduk dan ekonomi di Kab. Banyumas yaitu tumbuh dan berkembang di daerah-daerah datar untuk mengembangkan basis-basis perekonomian. Terlihat pada peta bagian timur Kabupaten Banyumas menunjukkan daerah datar yang dominan tempat berkembangnya aktivitas penduduk dan ekonomi. Dengan demikian, dapat disimpulkan bahwa mengapa terjadi disparitas antar daerah di Kabupaten Banyumas hal ini disebabkan perbedaan kondisi morfologi (topografi) daerah. Daerah - daerah datar cenderung dijadikan pusat aktivitas penduduk dan ekonomi daerah. 


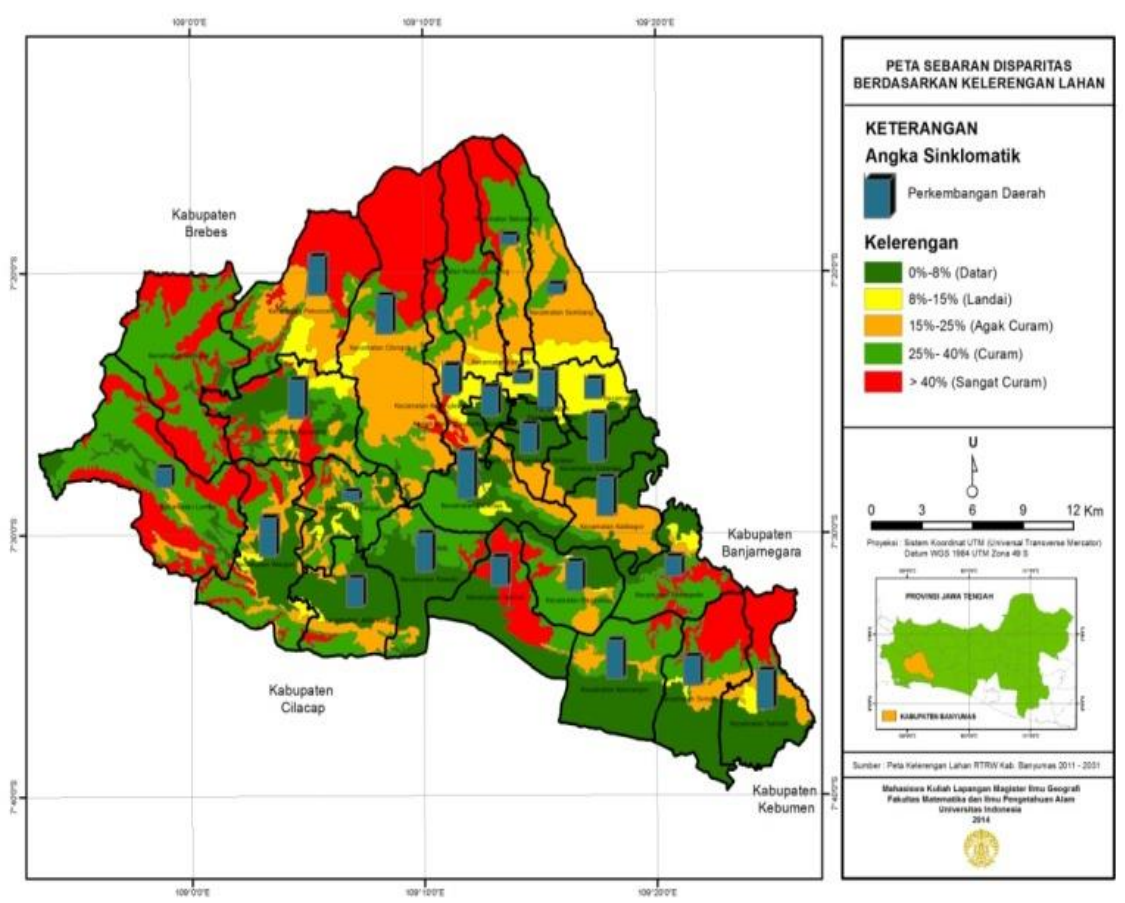

Gambar 3. Sebaran Disparitas Berdasarkan Kelerengan Lahan

Alasan lain yang menjadi ciri disparitas antar daerah seperti yang dijelaskan Rustiadi, dkk (2011) bahwa berdasarkan data kondisi permukiman juga dapat terlihat dari lokasi permukiman kumuh yang banyak terdapat pada daerah datar terutama daerah Purwokerto. Daerah Purwokerto menjadi pilihan 'kaum urban' untuk migrasi dapat disebabkan oleh kesulitan ekonomi. Kesulitan ekonomi tersebut dapat dilihat terutama dari sudut mata pencaharian di luar bagian timur yang menjadi penyebab penduduk mencari mata pencarian baru dengan urbanisasi ke pusat kota (Indarto, 2012).

Dalam kasus ini, daerah Purwokerto menjadi titik pusat 'kaum urban' sehingga terjadi aglomerasi ataupun polarisasi (pemusatan) penduduk di daerah bagian timur Kab. Banyumas. Akibat yang ditimbulkan juga dari fenomena tersebut adalah muncul permukiman kumuh (slum area) di daerah bagian timur. Hal ini juga terlihat ketika meng-obsevasi di Kecamatan yang menjadi sampel penelitian hanya ditemukan kemacetan lalu lintas di Purwokerto (bagian timur) terutama di depan Grand Aston dan di depan SMP N 1 Purwokerto. Fenomena permukiman kumuh tampak terlihat dari sebaran lokasi permukiman kumuh berdasarkan data yang diperoleh dari Bappeda (2014) yang dijelaskan pada Tabel 5.

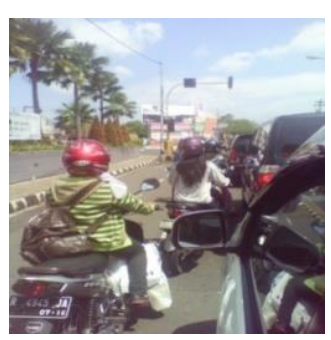

Gambar 4.

Kemacetan di depan Grand Aston Purwokerto

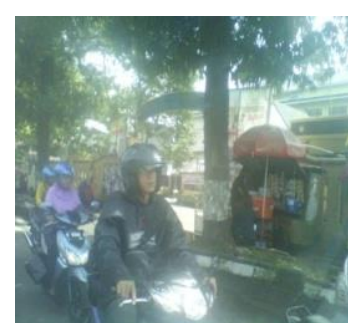

Gambar 5.

Kemacetan di depan SMP N 1 Purwokerto 
Tabel 5. Sebaran Lokasi Permukiman Kumuh

\begin{tabular}{|c|c|c|c|}
\hline No & Lokasi & $\begin{array}{c}\text { Luas } \\
\text { Kawasan } \\
(\text { Ha) }\end{array}$ & Keterangan \\
\hline 1 & $\begin{array}{l}\text { Kelurahan Purwokerto Lor } \\
\text { (Purwokerto Timur) }\end{array}$ & 53,12 & $\begin{array}{l}\text { Kauman, Karangturi, Karitas, Kauman } \\
\text { Baru, Kauman Lama, Kebondalem } \\
\text { (Komplek Makam) sampai selatan } \\
\text { Purwobakti dan Mangunjaya sisi timur }\end{array}$ \\
\hline 2 & $\begin{array}{l}\text { Kelurahan Purwokerto Wetan } \\
\text { (Purwokerto Timur) }\end{array}$ & 19,15 & $\begin{array}{l}\text { Kelapa Pagak, Penatusan, Kali Putih } \\
\text { (sebelah timur Pasar Wage), Kampung Baru }\end{array}$ \\
\hline 3 & $\begin{array}{l}\text { Kelurahan Grendeng } \\
\text { (Purwokerto Utara) }\end{array}$ & 22,71 & $\begin{array}{l}\text { RW 5,6,7 dan } 8 \text { (sebelah timur UNSOED) } \\
\text { Jl. Cendrawasih, Jl. Gunung Muria, Jl. } \\
\text { Gunung Slamet }\end{array}$ \\
\hline 4 & $\begin{array}{l}\text { Kelurahan Bancarkembar } \\
\text { (Purwokerto Utara) }\end{array}$ & 22,94 & $\begin{array}{l}\text { Dukuh Bandung (Jl. HR. Bunyamin, } \\
\text { Ringin Tirto dan Jatisari). }\end{array}$ \\
\hline 5 & $\begin{array}{l}\text { Kelurahan Kranji (Purwokerto } \\
\text { Timur) }\end{array}$ & 14,93 & $\begin{array}{l}\text { Bantaran Sungai Kranji, Belakang SMP } 1 \\
\text { Purwokerto, Depan SMP } 1 \text { Purwokerto } \\
\text { Arah Selatan, komplek Kalibener }\end{array}$ \\
\hline 6 & $\begin{array}{l}\text { Kelurahan Karangklesem } \\
\text { (Purwokerto Selatan) }\end{array}$ & 5,29 & $\begin{array}{l}\text { Kampung Sri Rahayu, Perum Sub Inti } \\
\text { (RW } 6 \text { RT 1-6) Jl. Nursin }\end{array}$ \\
\hline 7 & $\begin{array}{l}\text { Kelurahan Purwokerto Kidul } \\
\text { (Purwokerto Selatan) }\end{array}$ & 10,69 & $\begin{array}{l}\text { Pancurawis (RW 3,7,10), Samudra, } \\
\text { Perbatasan, Kali Bakal }\end{array}$ \\
\hline 8 & $\begin{array}{l}\text { Kelurahan Purwokerto Kulon } \\
\text { (Purwokerto Selatan) }\end{array}$ & 26,71 & Situmpur, Kongsen, Sudagaran (kawasan) \\
\hline 9 & $\begin{array}{l}\text { Kelurahan Berkoh (Purwokerto } \\
\text { Selatan) }\end{array}$ & 6,39 & $\begin{array}{l}\text { Komplek Apotik Jayanti, Karang Benda } \\
\text { (sebelah timur terminal) }\end{array}$ \\
\hline 10 & $\begin{array}{l}\text { Kelurahan Mersi (Purwokerto } \\
\text { Timur) }\end{array}$ & 9,73 & $\begin{array}{l}\text { Komplek pemotongan hewan kearah utara } \\
\text { (RW } 6 \text { sebelah selatan) }\end{array}$ \\
\hline 11 & $\begin{array}{l}\text { Kelurahan Arcawinangun } \\
\text { (Purwokerto Timur) }\end{array}$ & 31,58 & $\begin{array}{l}\text { Grumbul Kepatek (RW 1) sampai Mersi } \\
\text { (pasar ke selatan), RW } 10\end{array}$ \\
\hline 12 & $\begin{array}{l}\text { Kelurahan Karangwangkal } \\
\text { (Purwokerto Utara) }\end{array}$ & 21,74 & Kawasan sekitar UNSOED \\
\hline 13 & $\begin{array}{l}\text { Kelurahan Berkoh (Purwokerto } \\
\text { Timur) }\end{array}$ & 18,57 & $\begin{array}{l}\text { Grumbul Sokawera (sebelah utara } \\
\text { terminal) }\end{array}$ \\
\hline 14 & $\begin{array}{l}\text { Kelurahan Tanjung } \\
\text { (Purwokerto Selatan) }\end{array}$ & 11,25 & Grumbul Celeleng \\
\hline & Jumlah Total & 274,80 & \\
\hline
\end{tabular}

Sumber: Bappeda Kab. Banyumas, 2014

Berdasarkan Tabel 5. tampak dengan jelas bagaimana ciri disparitas antar daerah ditandai dengan fenomena permukiman kumuh yang meng-aglomerasi di daerah bagian timur Kab. Banyumas. Dimana dari 14 Kelurahan lokasi permukiman kumuh kesemuanya itu terletak di Kecamatan Purwokerto Utara, Kecamatan Purwokerto Timur, Purwokerto Selatan, Purwokerto Barat. Mengapa fenomena ini dapat terjadi, tentu disebabkan oleh faktor penarik dan pendorong dari proses urbanisasi itu sendiri. Misalnya, yang diungkapkan Pontoh dan Kustiwan (2009) bahwa faktor pendorong yang terkait proses urbanisasi diantaranya; semakin terbatasnya lapangan kerja di desa, kemiskinan di perdesaan, transportasi desa-kota semakin lancar, tingginya upah buruh di kota dari pada di desa, bertambahnya kemampuan membaca dan menulis, adat istiadat dianggap beban oleh masyarakat desa. Selain itu, ada juga faktor penarik yang mempengaruhi, seperti; kesempatan kerja lebih luas dan bervariasi di kota, tingkat upah yang lebih tinggi, lebih banyak kesempatan untuk maju, kesempatan rekreasi, dll. 


\section{KESIMPULAN}

Disparitas antar daerah di Kabupaten Banyumas berdasarkan Indeks Williamson tergolong kecil, jika membandingkannya dengan nilai PDRB antar daerah tampak adanya disparitas. Terdapat akumulasi penduduk di bagian timur Kabupaten Banyumas dengan kepadatan penduduk sangat tinggi. Permukiman kumuh (slume area) muncul di bagian timur karena disebabkan Polarisasi pembangunan di bagian timur Kabupaten Banyumas.

\section{DAFTAR PUSTAKA}

Ascani, A., Crescenzi, R., \& Iammarino, S. (2012). Regional Economic Development: A review. Search Working Paper, 1-27.

Bappeda Kab. Banyumas. (2014). Badan Perencanaan dan Pembangunan Daerah Kabupaten Banyumas.

Bintarto., \& Hadisumarno, S. (1991). Metode Analisa Geografi. LP3ES Edisi Keempat.

BPS. (2013). Banyumas Dalam Angka 2013. BAPPEDA dan BPS Kabupaten Banyumas.

Direktorat Jenderal Perumahan Dan Permukiman. (2011). Petunjuk Umum Pelaksanaan Peremajaan Lingkungan Permukiman Kumuh Di Perkotaan Dan Perdesaan. Jakarta.

Indarto, F. (2012). Konsep Dasar Analisis Spasial. Yogyakarta: Penerbit Andi.

Kepmentan 837/UM/11/1980 PP No. 3 Tahun 2008

Khomarudin. (1997). Menelusuri Pembangunan Perumahan dan Permukiman. Yayasan Real Estate Indonesia, Jakarta: PT. Rakasindo.

Krimi, M.S., Yusop, Z., \& Hook, L.S. (2010). Regional Development Disparities in Malaysia. Journal of American Science, 6(3), 70-78.

Lessmann, C. (2011). Spatial Inequality and Development - Is there an Inverted$U$ Relationship?. CESifo working paper: Fiscal Policy, Macroeconomics and Growth, No. 3622.

Masterplan Percepatan Dan Perluasan Pembangunan Ekonomi Indonesia 20112025.

Mohiuddin, S., \& Hashia, H. (2012). Regional Socioeconomic Disparities in the Kashmir Valley (India)-A Geographical Approach. Bulletin of Geography, 18(18), 85-98.

Pontoh, N. K., \& Kustiwan, I. (2009). Pengantar Perencanaan Perkotaan. Bandung: Penerbit ITB.

RPJMD Kab. Banyumas 2013 - 2018.

Rustiadi, dkk. (2011). Perencanaan dan Pengembangan Daerah Edisi Ketiga, Yayasan Pustaka Obor Indonesia, DKI Jakarta. kalimat Yayasan Pustaka Obor Indonesia, DKI Jakarta, kurang tab seperti diatas nya.

UU No. 38 Tahun 2004 Tentang Jalan.

UU Republik Indonesia Nomor 32 Tahun 2004 Tentang Pemerintahan Daerah.

UU Republik Indonesia Nomor 33 Tahun 2004 Tentang Perimbangan Keuangan antara Pemerintahan Pusat dan Pemerintahan Daerah. 